\title{
Distribution and Public Health Significance of Vibrio Pathogens Recovered from Selected Treated Effluents in the Eastern Cape Province, South Africa
}

\author{
Ayodeji C. Osunla ${ }^{1,2,3, *}$, Oluwatayo E. Abioye ${ }^{1,2,4}$ and Anthony I. Okoh ${ }^{1,2,5}$ (i) \\ 1 SAMRC Microbial Water Quality Monitoring Centre, University of Fort Hare, Alice 5700, South Africa; \\ abioyethayor@gmail.com (O.E.A.); AOkoh@ufh.ac.za (A.I.O.) \\ 2 Applied and Environmental Microbiology Research Group, Department of Biochemistry and Microbiology, \\ University of Fort Hare, Alice 5700, South Africa \\ 3 Department of Microbiology, Adekunle Ajasin University, Akungba-Akoko, Ondo-State P. M. B 001, Nigeria \\ 4 Department of Microbiology, Obafemi Awolowo University, Ile-Ife P. M. B. 13, Nigeria \\ 5 Department of Environmental Health Sciences, University of Sharjah, \\ Sharjah P. O. Box 555588, United Arab Emirates \\ * Correspondence: osunlacharles@gmail.com
}

check for

updates

Citation: Osunla, A.C.; Abioye, O.E.; Okoh, A.I. Distribution and Public

Health Significance of Vibrio

Pathogens Recovered from Selected Treated Effluents in the Eastern Cape Province, South Africa. Water 2021, 13, 932. https://doi.org/10.3390/ w13070932

Academic Editor: Milou M.L. Dingemans

Received: 19 February 2021

Accepted: 15 March 2021

Published: 29 March 2021

Publisher's Note: MDPI stays neutral with regard to jurisdictional claims in published maps and institutional affiliations.

Copyright: (c) 2021 by the authors. Licensee MDPI, Basel, Switzerland. This article is an open access article distributed under the terms and conditions of the Creative Commons Attribution (CC BY) license (https:// creativecommons.org/licenses/by/ $4.0 /)$.
Abstract: Treated sewage harbours pathogenic microbes, such as enteric bacteria and protozoa, are capable of causing several diseases. Some of these are emerging pathogens sometimes recovered in the absence of common water quality indicator organisms. The possibility of selected treatments plants serving as momentary reservoirs of Vibrio pathogens during a non-outbreak period was assessed. The occurrence and diversity of Vibrio pathogens were monitored for one year (December 2016 to November 2017) in the treated effluents and upstream and downstream areas of the receiving water bodies of two wastewater treatment plants (WWTPs), designated AL and TS. Physicochemical parameters of TS and AL WWTPs' water samples were analysed using a multiparameter meter (Hanna, model HI 9828, Padova, Italy) and a turbidimeter (HACH, model 2100P, Johannesburg, South Africa). Water samples were augmented with alkaline peptone water and cultured on thiosulfate citrate bile salts sucrose agar at $37^{\circ} \mathrm{C}$ for $24 \mathrm{~h}$. The recovered probable pathogens were confirmed via PCR amplification, using primers specific for Vibrio species of public health significance. The distribution of Vibrio species positively and significantly $(p<0.01)$ correlated with turbidity $(r=0.630)$, temperature $(r=0.615)$, dissolved oxygen $(r=0.615), \mathrm{pH}(\mathrm{r}=0.607)$, biological oxygen demand $(r=0.573)$, total dissolved solid $(r=0.543)$, total suspended solid $(r=0.511)$, electrical conductivity $(r=0.499)$, residual chlorine $(r=0.463)$ and salinity $(r=0.459)$. The densities of Vibrio species were found to be significantly higher $(p<0.05)$ in effluents from both AL and TS WWTPs than upstream and downstream of the receiving rivers across the sampling regime. Furthermore, the maximum Vibrio species density across the sampling regime were observed during the warmer Summer and Spring season. Moreover, six medically important Vibrio species were detected in the water samples, indicating that the methods employed were efficient in revealing that WWTPs are potential reservoirs of Vibrio pathogens, which could pose a substantial public health risk if the receiving water is used for domestic purposes. Our findings further strengthen existing calls for the inclusion of emerging bacterial pathogens, including Vibrio species, as water quality indicators by the South African Department of Water Affairs. Hence, we recommend regular monitoring of treated effluents and receiving water bodies to ensure early control of potential outbreaks of vibriosis and cholera.

Keywords: Vibrio species; treated effluents; freshwater; public health; wastewater treatment plants

\section{Introduction}

Treated effluents and their contiguous natural water resources, such as rivers, streams and brackish water are known to harbour copious amounts of waste products, including 
enteric pathogens [1]. The inherent traits possessed by these microorganisms to persist in conservative treated effluents might pose a major risk to human health, considering the domestic use of highly contaminated surface waters [2]. Wastewater effluents are potential reservoirs and transporters of pathogenic Vibrio species, serving as an enabling environment for the pathogens to thrive against unfavourable conditions [3,4]. Despite the incredible efforts of international bodies and water management organizations, such as the World Health Organization (WHO) and Water Research Commission (WRC), to upgrade and maintain water treatment standards, the prevalence of waterborne infections remains evident in developing countries [5]. Furthermore, the occurrence of potentially pathogenic microbes in effluents from wastewater treatment plant and adjacent river water indicates that the wastewater treatment plants (WWTPs) are not effective in eradicating all pathogens as expected [6]. Hence, treatment plants have been implicated in the distribution of enteric pathogens, such as the main 12 known pathogenic Vibrio species to human, in contaminating freshwater ecosystem $[7,8]$. Vibrio species are known autochthonous populations found in freshwaters and marine sediments worldwide [9,10]. Several species of Vibrio are known to cause a number of diseases in human, including cholera, gastroenteritis and primary septicaemia, and their infections arise from the ingestion of contaminated foods, water, undercooked seafoods and through wounded skin getting direct contact with contaminated water [11-14]. The upsurge of potentially pathogenic Vibrio species in freshwater resources is partially attributable to global warming induced by hydro-climatic changes [15]. Over the years WWTPs across South Africa have been found to discharge inadequately treated effluents with various enteric pathogens, such as Vibrio species [16]. Moreover, existing treatment regulations and guidelines, which use common indicator organisms to assess portable water and treated effluents, may underestimate potential health risks from many pathogenic microbes [17]. The South African Department of Water and Sanitation, in its Performance Audit on Water Infrastructure meeting in 2017, reported that 40 to $50 \%$ of the 1400 wastewater works are in a poor state at medium to high risk. Additionally, the treatment of wastewater generated in rural and peri-urban areas of the Republic of South Africa (rural settlement wastewaters) is either absent or scarce [18]. This is rather disturbing, considering that $19 \%$ of rural dwellers in South Africa absolutely rely on local freshwater resources for most of their domestic activities without further treatment [18]. South Africa is located in a semiarid region and receives very little rainfall, resulting in shortage of potable water. Most individuals, therefore, resort to water from unprotected sources, such as rivers, boreholes and dams, for daily activities, such as irrigation, cooking and even drinking [9]. Besides, shockingly high cases of waterborne disease outbreaks, associated with a lack of fundamental sanitation and infrastructure, have been documented in poverty-wracked settlements [2]. Therefore, there is an immense need for regular monitoring of the occurrence and distribution of clinically important Vibrio species in the effluents from WWTPs. Hence, this study evaluated treated effluents from selected WWTPs in the Eastern Cape Province of South Africa and its receiving watersheds as potential reservoirs of Vibrio pathogens. Interestingly, this is the first time that this kind of study will be carried out at the selected WWTPs.

\section{Materials and Methods}

\subsection{Study Area and Water Collections}

A description of the two selected WWTPs, designated AL WWTP and TS WWTP, are presented in Table 1. Our sampling of both AL and TS was approved by the appropriate authority. Treated effluents and receiving water samples were collected between December 2016 and November 2017 at the end-phase of treatment in WTTPs and $\sim 500 \mathrm{~m}$ up and downstream of the treated effluent release point into freshwater bodies. Samples were collected in duplicates in $1 \mathrm{~L}$ germ-free bottles against the river tidal flow, transported in ice packs cooler to our laboratory and processed within $6 \mathrm{~h}$. The sampling bottles already contained 3\% sodium thiosulphate to minimize the influence of lingering chlorine on indigenous microorganisms. 
Table 1. Detailed description of AL and TS wastewater treatment plants.

\begin{tabular}{ccc}
\hline WWTPs & AL & TS \\
\hline Municipality & Sarah Baartman District & Chris Hani District \\
Technology & Activated Sludge & Stabilization pond \\
Geographic location & S33.31612626 ${ }^{\circ}$, E26.107717 & S32.045122, E27.810904 \\
Design capacity (ML/d) & 1.1 & NI \\
Receiving river & Boesman & Tsomo \\
Population statistics (2016) & 138,182 households & 194,291 households \\
\hline
\end{tabular}

NI = No information.

\subsection{Determination of Physicochemical Parameters}

Synchronously with water sample collection for bacteriological examination at each sampling site, environmental variables were measured using a multi-parameter meter (Hanna, model HI 9828, Padova, Italy) and a turbidimeter. Physicochemical parameters of AL and TS WWTPs water samples such as temperature $\left({ }^{\circ} \mathrm{C}\right), \mathrm{pH}$, electrical conductivity (EC) $(\mu \mathrm{S} / \mathrm{cm})$, dissolved oxygen (DO, $\mathrm{mg} / \mathrm{L})$, turbidity (NTU), TDS (mg/l) salinity (PSU), total suspended solids (TSS, $\mathrm{mg} / \mathrm{L}$ ) and total dissolved solids (TDS, $\mathrm{mg} / \mathrm{L}$ ) were measured at the sampling site. The biochemical oxygen demand (BOD, $\mathrm{mg} / \mathrm{L}$ ) of the samples was measured after 5 days of incubation in the dark under ambient condition using a BOD meter (HACH, HQ 40d, Johannesburg, South Africa). All physicochemical parameters were determined following standard instrumental procedures.

\subsection{Bacterial Strains}

Six of the seven Vibrio strains used in this study were sourced from the Leibniz Institute DSMZ-German Collection of Microorganisms and Cell Cultures $\mathrm{GmbH}$, including Vibrio alginolyticus DSM 2171, V. parahaemolyticus (DSM 10027), V. fluvialis (DSM 19283), V. mimicus (DSM 19130), V. vulnificus (DSM 10143) and V. alginolyticus (DSM 19130). A locally isolated strain of $V$. cholerae was used as a reference organism for forming $V$. cholerae isolates in this study.

\subsection{Bacterial Isolation and Enrichments of Samples}

Treated effluent and receiving water body samples were serially diluted using the standard method prescribed by [19]. Ten-fold serial dilution up to power of four was carried out on all samples by adding $100 \mathrm{~mL}$ of sample to $900 \mathrm{~mL}$ sterile distilled water. Then, $100 \mathrm{~mL}$ of each dilution was filtered using a standard membrane MF-Millipore filter ( $47 \mathrm{~mm}, 0.45 \mu \mathrm{m}$ pore size), following [20], which was then aseptically transferred to thiosulfate citrate bile salts sucrose (TCBS) agar (Oxoid, Cambridge, UK) and cultured at $37^{\circ} \mathrm{C}$ for $24 \mathrm{~h}$ to determine the presumptive microbial load. After the incubation period, distinct yellow and green colonies observed on the plates were counted as presumptive Vibrio isolates. The yellow and green colonies $(\mathrm{X})$ were expressed in colony-forming units per $100 \mathrm{~mL}(\mathrm{CFU} / 100 \mathrm{~mL})$ and $\log$ transformed $(\log (1+\mathrm{X}))$. Moreover, for enhanced isolation of Vibrio spp. of interest, $10 \mathrm{~mL}$ of water sample was seeded into $90 \mathrm{~mL}$ alkaline peptone water (APW) in a $250 \mathrm{~mL}$ conical flask. The conical flasks were agitated gently for $2 \mathrm{~min}$ for even mixture of APW and water sample and incubated at $37^{\circ} \mathrm{C}$ for $24 \mathrm{~h}$. Then, a loopful of the biofilm formed as a thin layer at the surface of the APW sample experimental set-up was carefully streaked on TCBS agar and incubated at $37^{\circ} \mathrm{C}$ for $24 \mathrm{~h}$. Distinct yellow and green colonies observed on the plates were randomly selected, and selected isolates were sub-cultured onto fresh TCBS to obtain pure cultures. The pure probable isolates were subsequently cultured at $37^{\circ} \mathrm{C}$ for $24 \mathrm{~h}$ on freshly prepared nutrient agar and then preserved in $20 \%$ glycerol stocks at $-80{ }^{\circ} \mathrm{C}$ for subsequent studies.

\subsection{Confirmation of Probable Vibrio Isolates}

DNA from recovered isolates was carefully extracted via the boiling method [21]. The isolates were then confirmed as member of Vibrio genus using the DNA template and the 
Vibrio genus-specific primer that targets the region (700 bp-1325 bp) of 16S rRNA gene in a PCR assay, as described in one of the earlier study from our laboratory. The primer sequence to confirm the identity of the probable Vibrio species isolates is presented in Table 2. The $25 \mu \mathrm{L}$ PCR cocktail included $5 \mu \mathrm{L}$ DNA templates, $12.5 \mu \mathrm{L} 2 \times$ Taq Master Mix of Standard Buffer (BioLabs, Hitchin, UK), $1 \mu \mathrm{L}$ each of $10 \mu \mathrm{M}$ forward and reverse primers and $5.5 \mu \mathrm{L}$ nuclease-free water. The PCR protocol for single enzyme activation was as follows: pre-denaturation at $93{ }^{\circ} \mathrm{C}$ for $15 \mathrm{~min}, 35$ cycles of denaturation at $92{ }^{\circ} \mathrm{C}$ for $40 \mathrm{~s}$, annealing at $57^{\circ} \mathrm{C}$ for $60 \mathrm{~s}$, extension at $72{ }^{\circ} \mathrm{C}$ for $90 \mathrm{~s}$ and final extension at $75^{\circ} \mathrm{C}$ for $7 \mathrm{~min}$. V. fluvialis (DSM 19283) was used as a positive control.

Table 2. Characteristics of primers used for PCR amplification of genus- and species-specific genes.

\begin{tabular}{|c|c|c|c|}
\hline Specie & Sequence & Size bp & References \\
\hline \multirow{2}{*}{ Vibrio genus } & F: CGG TGA AAT GCG TAG AGA T & \multirow{2}{*}{663} & \multirow{2}{*}[22,23]{} \\
\hline & R: TTA CTA GCG ATT CCG AGT TC & & \\
\hline \multirow{2}{*}{ V. cholerae } & F: CAC CAA GAA GGT GAC TTT ATT GTG & \multirow{2}{*}{304} & \multirow{2}{*}[24,25]{} \\
\hline & R: GGT TTG TCG AAT TAG CTT CAC C & & \\
\hline \multirow{2}{*}{ V. parahaemolyticus } & F: GCA GCT GAT CAA AAC GTT GAG T & \multirow{2}{*}{897} & \multirow{2}{*}[23,26]{} \\
\hline & R: ATT ATC GAT CGT GCC ACT CAC & & \\
\hline \multirow{2}{*}{ V. vulnificus } & F: GTC TTA AAG CGG TTG CTG C & \multirow{2}{*}{410} & \multirow{2}{*}{ [23] } \\
\hline & R: CGC TTC AAG TGC TGG TAG AAG & & \\
\hline \multirow{2}{*}{ V. Fluvialis } & F: GAC CAG GGC TTT GAG GTG GAC GAC & \multirow{2}{*}{217} & \multirow{2}{*}[23,27]{} \\
\hline & R: AGG ATA CGG CAC TTG AGT AAG ACT C & & \\
\hline \multirow{2}{*}{ V. Mimicus } & F: GGT AGC CAT CAG TCT TAT CAC G & \multirow{2}{*}{390} & \multirow{2}{*}{ [28] } \\
\hline & R: ATC GTG TCC CAA TAC TTC ACC G & & \\
\hline \multirow{2}{*}{ V. alginolyticus } & F: GAG AAC CCG ACA GAA GCG AAG & \multirow{2}{*}{337} & \multirow{2}{*}{ [29] } \\
\hline & R: CCT AGT GCG GTG ATC AGT GTT G & & \\
\hline
\end{tabular}

\subsection{Delineation of Vibrio Species Isolates}

Species-specific primers were used to delineate the confirmed isolates into six different species. Appropriate primer sets (Table 2) were used in the PCR assay to authenticate the isolates that falls within the Vibrio species of interest in this study. A triplex PCR was employed for the concurrent delineation of $V$. alginolyticus, $V$. fluvialis and $V$. vulnificus, while a duplex PCR procedure was also used for concurrent confirmation of $V$. mimicus, and $V$. cholerae Vibrio parahaemolyticus was confirmed using simplex PCR. All protocols were as described in earlier studies [30,31]. The thermal condition for the PCR is as described under Confirmation of Probable Vibrio isolates section above except that annealing temperatures for triplex, duplex and singleplex PCR were 66.3, 54.5 and $64{ }^{\circ} \mathrm{C}$, respectively.

The positive controls used were $V$. parahaemolyticus (DSM 10027), V. vulnificus (DSM 10143), V. fluvialis (DSM 19283), V. mimicus (DSM 19130) and V. alginolyticus (DSM 19130) and one locally isolated $V$. cholerae. E. coli ATCC 35150 was employed as a negative control for all the PCR assays.

\subsection{Statistical Analysis}

The entire sampling regime was grouped into four seasons: Winter (June, July, August), Spring (September, October, November), Summer (December, January, February) and Autumn (March, April, May). We hypothesized that there is no significant difference in mean densities of Vibrio spp. and physicochemical parameters across seasons. Data generated (density and physiochemical parameters) were subjected to Shapiro-Wilk normality test. Afterwards, the seasonal mean densities and values for physicochemical parameters were compared across seasons using one-way analysis of variance (ANOVA) and Fisher's least significant difference (LSD) post hoc test at $p<0.05$. Pearson correlation analysis was performed to understand the relationship between Vibrio species density and physicochemical parameters at each of the WWTPs. The statistical methods were so chosen because the data we generated for each of our variables were normally distributed. Statistical Package for Social Sciences (SPSS) version 20 was used for the statically analysis. 


\section{Results}

All physicochemical parameters (electrical conductivity, total dissolved solids, salinity, temperature, dissolved oxygen, biological oxygen demand, total suspended solids, turbidity and residual chlorine) measured except residual chlorine correlated positively (Table 3 ) with Vibrio species density at high significance level $(p<0.01)$ at ALEFF. The distribution of Vibrio species density correlated positively and significantly with temperature at TSUP $(\mathrm{r}=0.545, p<0.01)$; TSEFF $(\mathrm{r}=0.526, p<0.01)$; TSDW $(\mathrm{r}=0.517, p<0.01)$; ALUP $(\mathrm{r}=0.509$, $p<0.01)$ and ALDW $(\mathrm{r}=0.607, p<0.01)$, dissolved oxygen at TSEFF $(\mathrm{r}=0.421, p<0.05)$, total suspended solid at TSUP $(0.387, p<0.05)$, turbidity at TSUP $(\mathrm{r}=0.386 p<0.05)$, electrical conductivity at ALUP $(r=0.449, p<0.05)$ and ALDW $(r=0.331, p<0.05)$, total dissolved solid at ALUP $(\mathrm{r}=0.543, p<0.01)$ and ALDW $(\mathrm{r}=0.350, p<0.05)$, pH at ALUP $(\mathrm{r}=0.377$, $p<0.05)$ and ALDW $(\mathrm{r}=0.607, p<0.05)$, salinity at ALUP $(\mathrm{r}=0.390, p<0.05)$, residual chlorine at TSDW $(r=0.463, p<0.05)$, but Vibrio species density correlated negatively and significantly with dissolved oxygen at TSUP. Temperature is the only parameter that correlated positively at high significant level $(p<0.01)$ with the distribution of Vibrio species density at all sampling points (Table 3).

Table 3. The correlation matrix between the Vibrio species density and water quality indexes of AL and TS WWTPs.

\begin{tabular}{|c|c|c|c|c|c|c|}
\hline \multicolumn{7}{|c|}{ TS WWTPs } \\
\hline Site & $\begin{array}{l}\text { Physicochemical } \\
\text { Parameters }\end{array}$ & $\begin{array}{c}\text { Cfu/ } \\
\text { mLCorel Coeff }\end{array}$ & Site & $\begin{array}{c}\text { Cfu/ } \\
\text { mLCorel Coeff }\end{array}$ & Site & $\begin{array}{c}\text { Cfu/ } \\
\text { mLCorel Coeff }\end{array}$ \\
\hline \multirow{10}{*}{ TSUP } & $\mathrm{pH}$ & -0.327 & \multirow{10}{*}{ TSEFF } & 0.218 & \multirow{10}{*}{ TSDW } & 0.27 \\
\hline & Cond & -0.076 & & -0.232 & & 0.026 \\
\hline & TDS & -0.076 & & -0.182 & & 0.044 \\
\hline & Sal & -0.064 & & -0.175 & & 0.014 \\
\hline & Temp & $0.545^{* *}$ & & $0.526^{* *}$ & & $0.517^{* *}$ \\
\hline & DO & $-0.393 *$ & & $0.421 *$ & & -0.012 \\
\hline & BOD & 0.304 & & 0.332 & & -0.029 \\
\hline & TSS & 0.387 * & & 0.298 & & 0.13 \\
\hline & Turb & 0.386 * & & 0.275 & & 0.134 \\
\hline & FreeCl 2 & & & 0.238 & & $0.463^{* *}$ \\
\hline \multicolumn{7}{|c|}{ AL WWTPs } \\
\hline Sites & $\begin{array}{l}\text { Physicochemical } \\
\text { parameters }\end{array}$ & $\begin{array}{c}\text { Cfu/ } \\
\text { mLCorel coeff }\end{array}$ & Site & $\begin{array}{c}\text { Cfu/ } \\
\text { mLCorel coeff }\end{array}$ & Site & $\begin{array}{c}\mathrm{Cfu} / \\
\text { mLCorel coeff }\end{array}$ \\
\hline \multirow{10}{*}{ ALUP } & $\mathrm{pH}$ & 0.377 * & \multirow{10}{*}{ ALEFF } & $0.497^{* *}$ & \multirow{10}{*}{ ALDW } & $0.607^{* *}$ \\
\hline & Cond & $0.449^{* *}$ & & $0.488^{* *}$ & & $0.331 *$ \\
\hline & TDS & $0.543^{* *}$ & & $0.452 * *$ & & 0.350 * \\
\hline & Sal & 0.390 * & & $0.459 * *$ & & 0.246 \\
\hline & Temp & $0.509 * *$ & & $0.615^{* *}$ & & $0.559 * *$ \\
\hline & $\mathrm{DO}$ & -0.04 & & $0.615^{* *}$ & & 0.07 \\
\hline & BOD & 0.212 & & $0.575 * *$ & & 0.281 \\
\hline & TSS & -0.185 & & $0.511^{* *}$ & & 0.103 \\
\hline & Turb & -0.087 & & $0.630 * *$ & & 0.197 \\
\hline & FreeCl$_{2}$ & & & 0.137 & & 0.107 \\
\hline
\end{tabular}

Note: Corel coeff, correlation coefficient; Cond, electrical conductivity; TDS, total dissolved solids; Sal, salinity; Temp, temperature; DO, dissolved oxygen; BOD, biological oxygen demand; TSS, total suspended solids; Turb, turbidity; $\mathrm{FreeCl}_{2}$, residual chlorine. Significant correlation coefficient at: ${ }^{*} p<0.05 ;{ }^{* *} p<0.01$.

The seasonal variation in the number of culturable Vibrio populations recovered from water samples collected from TS and AL WWTPs and the neighbouring freshwater bodies across different seasons are shown in Figure 1a,b. Additionally, Table 4 show the significant echelons ( $p$ values) of the statistical comparison of the average annual and seasonal mean of presumptive Vibrio species observed for both AL and TS WWTPs, respectively. The means of presumptive Vibrio species density in both WWTPs and the receiving water bodies throughout the sampling regime ranged from $1.05 \pm 0.23$ to $2.08 \pm 0.07 \mathrm{Log} \mathrm{cfu} / \mathrm{mL}$ (Figure 1a,b). The annual mean 
Vibrio species densities at the final effluent discharge points are significantly higher than the observed densities at both the up-stream and the down-stream of the two WWTPs. Additionally, the annual mean density at the down-stream is significantly higher than that at upstream for both WWTPs. In the case of AL treatment plant, mean Vibrio populations $(0.81 \pm 0.10 \mathrm{Log}$ CFU $/) \mathrm{mL}$, estimated from TCBS counts, were lowest during Winter (June) at the upstream point (ALUP), while the highest abundance $(2.14 \pm 0.00 \mathrm{Log}$ CFU/) $\mathrm{mL}$ was observed during Winter (July) at the discharged point of effluents from the treatment plant (ALEFF). At TS WWTP, the lowest density of $0.78 \pm 0.09 \mathrm{Log}$ CFU $/ \mathrm{mLwas}$ observed in Winter (June) at TSUP, while the highest density of $2.07 \pm 0.00 \mathrm{Log}$ CFU/mLwas observed in Spring (October) at TSEFF. On the other hand, density varies across seasons at the two WWTPs. The average density in the Summer was significantly higher than that for other seasons except in Autumn. Additionally, density recorded in Spring was significantly higher than that observed in Autumn and Winter, while the density observed for Autumn was significantly higher than density observed for Winter. All recovered presumptive Vibrio isolates were further confirmed via PCR assay, with expected amplicon sizes ( $663 \mathrm{bp})$ of Vibrio genus-specific 16S rRNA region obtained (Figure 2). Figures 3 and 4 showed the electrophoresis gel images for duplex PCR amplicons of $V$. mimicus and $V$. cholerae and triplex PCR for the identification of $V$. fluvialis, $V$. alginolyticus and $V$. vulnificus, respectively. Additionally, the agarose gel image of conventional PCR amplicons of $V$. parahaemolyticus is presented in Figure 5. Consequently, the distribution of confirmed Vibrio isolates considered across all seasons is presented in Figure $6 a, b$. The figures show that a major percentage of the Vibrio species were recovered from TS and AL WWTP samples during warm periods of our sampling regime. The overall occurrence of Vibrio species was 60\% (76/127) and 75\% $(86 / 115)$ in TS and AL WWTPs water samples, respectively. Among the positive Vibrio species recovered from TS WWTP $(n=127), V$. cholerae showed the highest rate of detection (33.8\%), trailed by $V$. mimicus and $V$. fluvialis (11 and 9.4\%, correspondingly). The remaining confirmed species ( $V$. alginolyticus, $V$. vulnificus and $V$. parahaemolyticus) comprised between 0 and $5.5 \%$. On the other hand, the abundances of the selected confirmed Vibrio species $(n=115)$ recovered from AL WWTP water samples were 34, 19, 13, 6, 2 and $1 \%$ for $V$. cholerae, $V$. mimicus, $V$. fluvialis, $V$. parahaemolyticus, $V$. vulnificus and $V$. alginolyticus, respectively. In addition, the Vibrio populations from treated effluents in this study were dominated by V. cholerae and V. mimicus across all seasons (Summer, Winter, Autumn and Spring), with Vibrio alginoliticus and Vibrio vulnificus having the lowest population throughout the sampling regime. The average seasonal comparison of six confirmed clinically important Vibrio species from TS and AL WWTPs, respectively, is presented in Table 5. The abundances of the selected Vibrio species within Autumn vs. Spring, Winter vs. Spring (TS WWTP) and Winter vs. Spring (AL WWTP) were not significantly different for both treatment plants (Table 5). However, significant differences $(p<0.05)$ were observed when the seasonal occurrences of Vibrio spp. in samples from both TS and AL WTTPs were compared for seasons: Summer vs. Autumn, Summer vs. Winter, Summer vs. Spring, Autumn vs. Winter and Autumn vs. Spring.

Table 4. Statistical comparison of the average annual presumptive Vibrio densities in TS and AL wastewater treatment plants.

\begin{tabular}{cccc}
\hline \multicolumn{2}{c}{ TS Wastewater Treatment Plant } & \multicolumn{2}{c}{ AL Wastewater Treatment Plant } \\
\hline Site Types & $p$ values & Site Types & $p$ values \\
TSUP vs. TSEFF & $<0.0001^{*}$ & ALUP vs. ALEFF & $<0.0001^{*}$ \\
TSUP vs. TSDW & $0.007^{*}$ & ALUP vs. ALDW & $<0.0001^{*}$ \\
TSEFF vs. TSDW & $<0.0001^{*}$ & ALEFF vs. ALDW & $<0.0001^{*}$ \\
\hline
\end{tabular}

\footnotetext{
* = Significant different.
} 


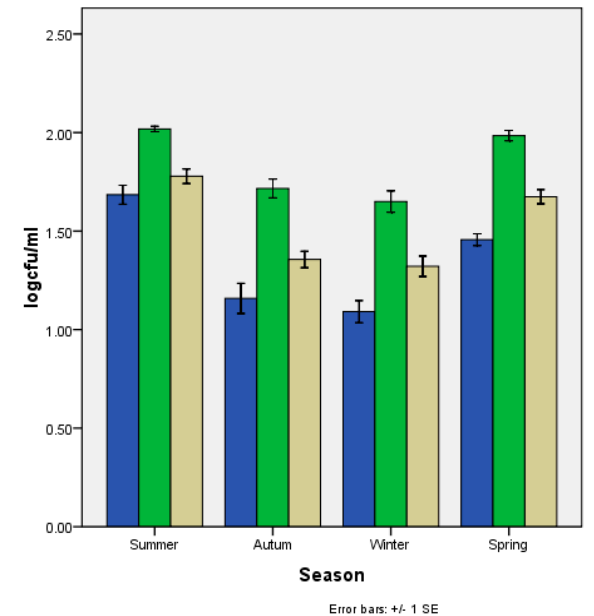

(a)

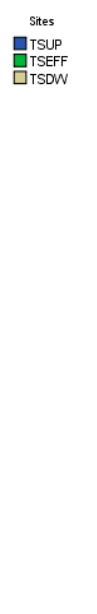

Figure 1. (a). Mean seasonal presumptive Vibrio species densities of TS WWTP. (b). Mean seasonal presumptive Vibrio species densities of AL WWTP. TSUP, upstream discharge point; TSEFF, effluent; TSDW, downstream discharge point, bars on column showed standard error of three replicates.

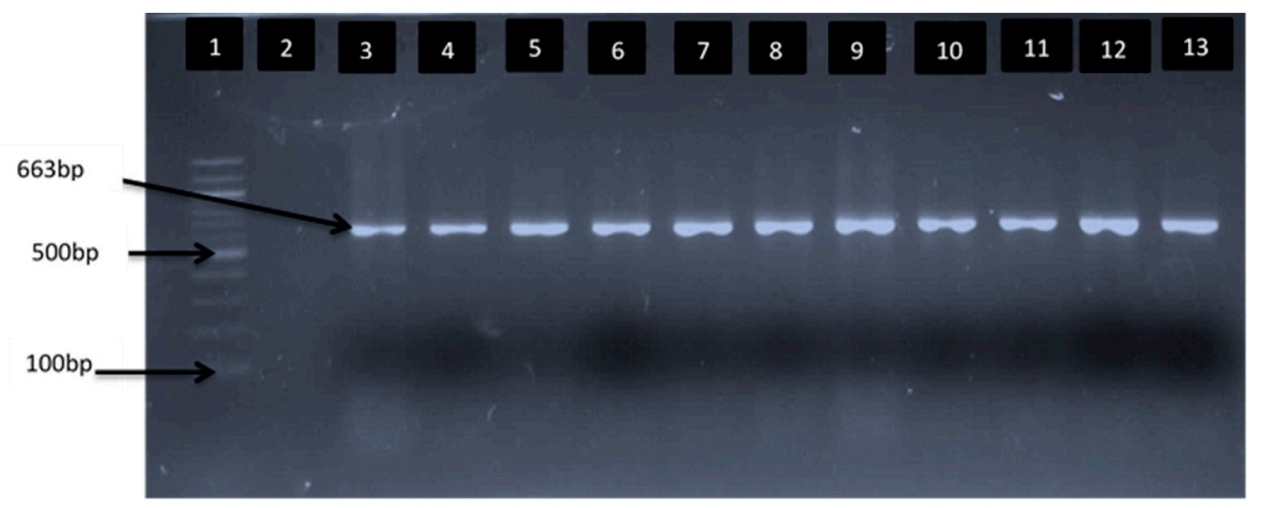

Figure 2. Agarose gel image showing PCR amplicons of the fla E gene, specific for $V$. parahaemolyticus. Lane 1, molecular weight marker (100 bp); lane 2, negative control; lane 3, positive control (DSM 19130); lanes 4-12, positive isolates.

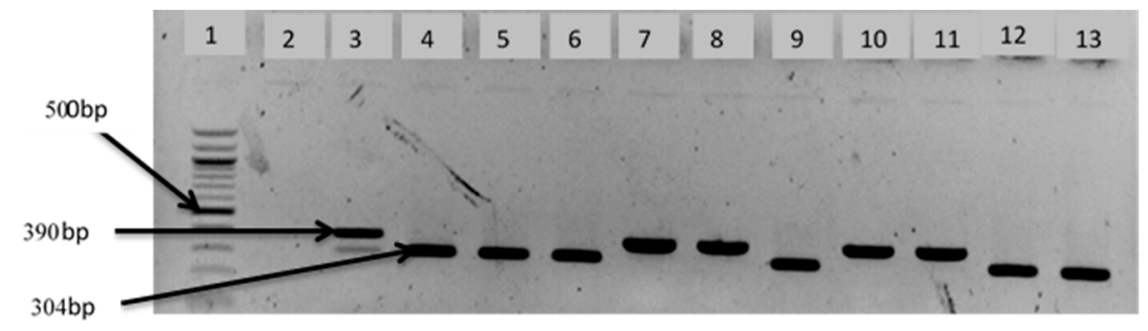

Figure 3. Agarose gel with duplex PCR amplicons showing $\mathrm{OmpW}$ and vhm gene regions specific for $V$. cholerae and $V$. mimicus, respectively. Lane 1, molecular weight marker (100 bp); lane 2, negative control; lane 3, positive control locally sourced V. cholerae and DSM 19130); lanes 4-6, 9, 12 and 13, V. cholerae positive isolates; lanes 7, 8, 10 and 11, $V$. mimicus-positive isolates. 


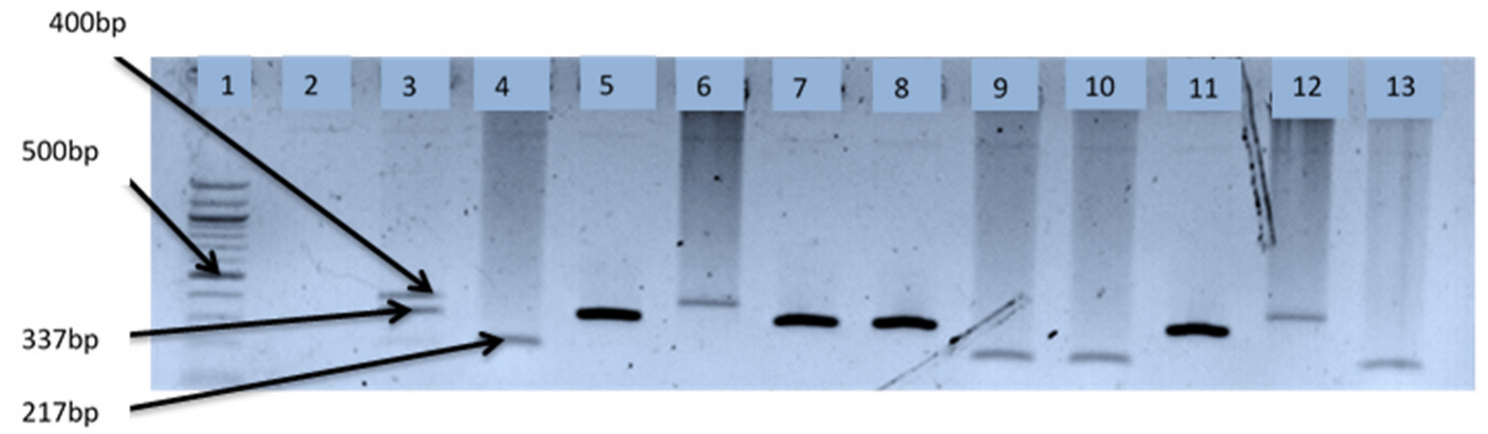

Figure 4. Agarose gel with triplex PCR amplicons showing GroEl, ToxR and GyrB genes regions specific for $V$. vulnificus, $V$. fluvialis and V. alginolyticus, respectively. Lane 1, molecular weight marker (100 bp); lane 2, negative control; lane 3, positive control DSM 19130, DSM 10143, DSM 19283); lanes 4, 9, 10 and 13, V. fluvialis positive isolates; lanes 5, 7, 8 and 11, V. alginolyticus positive isolates; lanes 6 and 12, V. vulnificus positive isolates.

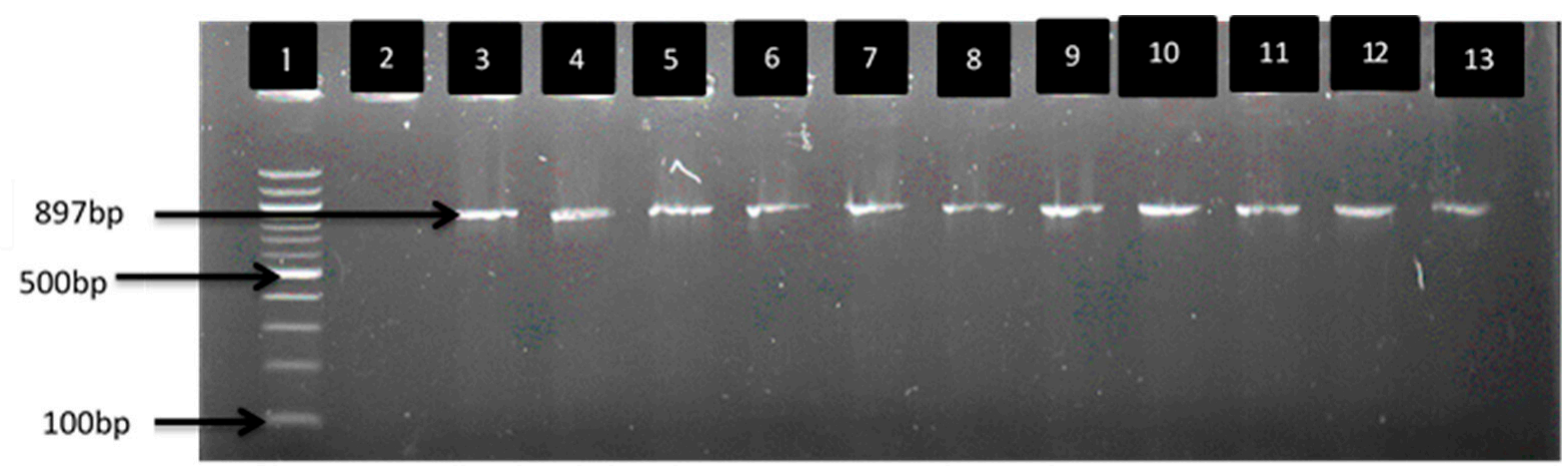

Figure 5. Agarose gel with PCR amplicons showing fla E gene specific for V. parahaemolyticus. Lane 1, molecular weight marker (100 bp); lane 2, negative control; lane 3, positive control (DSM 19130); lanes 4-12, positive isolates.

Table 5. Significant levels of the statistical comparison of average seasonal presumptive Vibrio densities in TS and AL wastewater treatment plants.

\begin{tabular}{cccc}
\hline \multicolumn{2}{c}{ TS Wastewater Treatment Plant } & \multicolumn{1}{c}{ AL Wastewater Treatment Plant } \\
\hline Seasons & $p$ values & Seasons & $p$ values \\
Summ vs. Autu & 0.524 & Summ vs. Autu & 0.394 \\
Summ vs. Wint & $<0.0001^{*}$ & Summ vs. Wint & $<0.0001^{*}$ \\
Summ vs. Spri & $<0.0001^{*}$ & Summ vs. Spri & $0.001^{*}$ \\
Autu vs. Wint & $<0.0001^{*}$ & Autu vs. Wint & $<0.0001^{*}$ \\
Autu vs. Spri & $<0.0001^{*}$ & Autu vs. Spri & $0.009^{*}$ \\
Wint vs. Spri & $0.011^{*}$ & Wint vs. Spri & $0.014^{*}$ \\
\hline
\end{tabular}

*, significantly different; Summ, Summer; Autu, Autumn; Wint, Winter; Spri, Spring. 


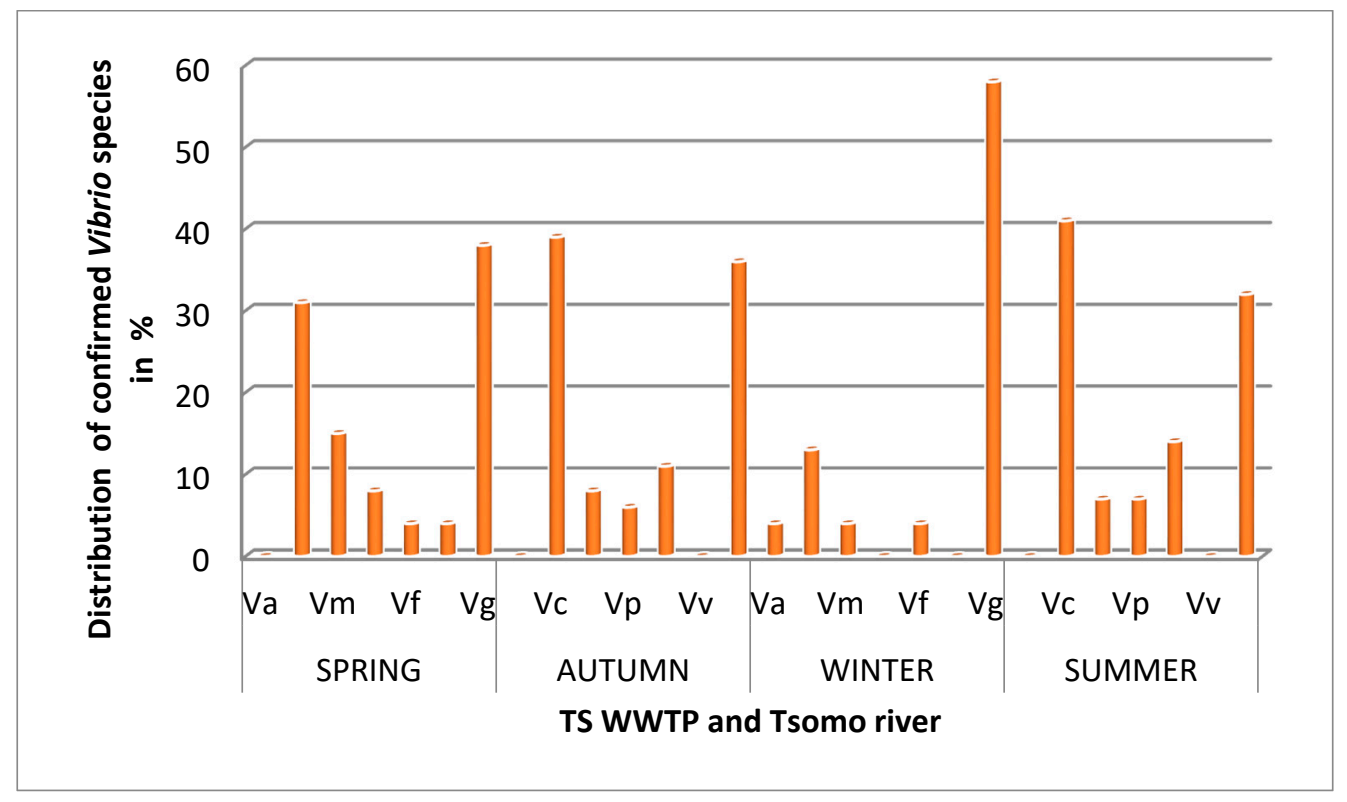

(a)

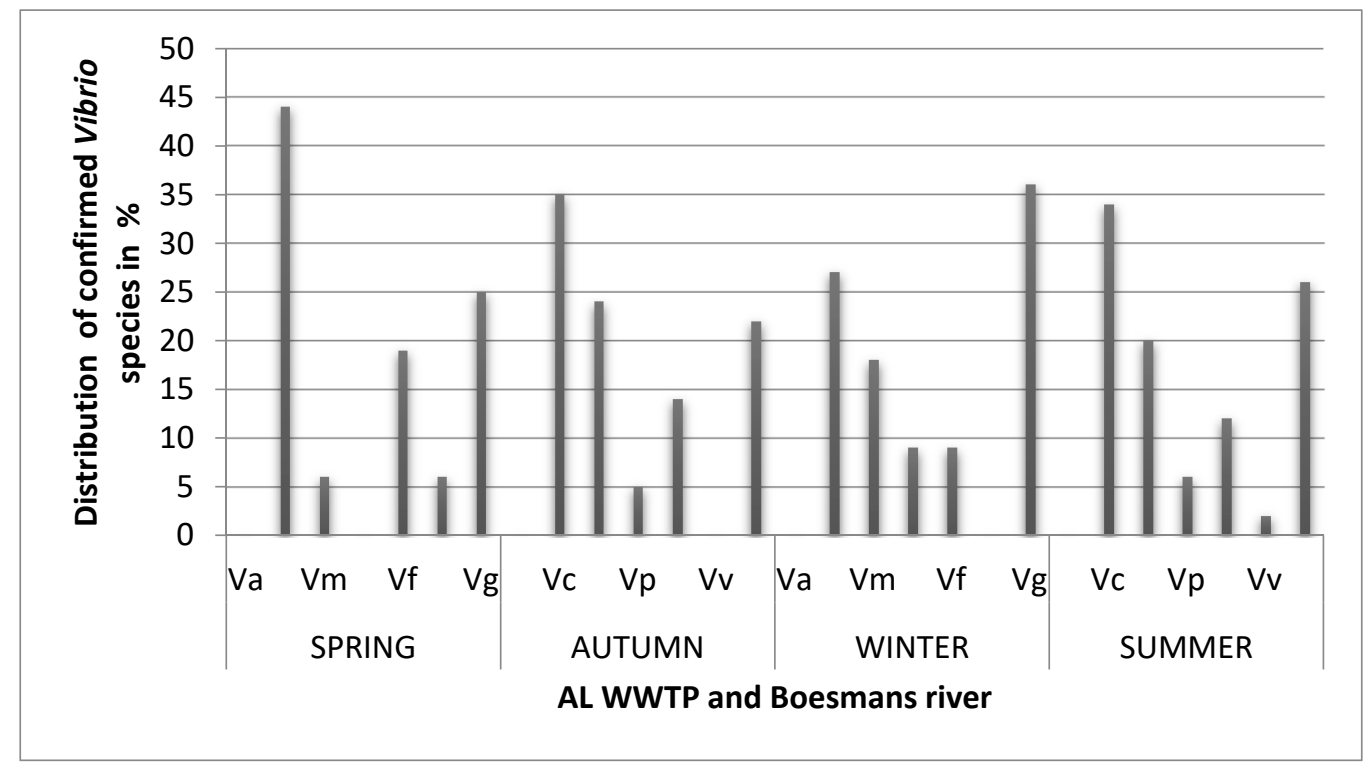

(b)

Figure 6. (a): Percentage distribution of Vibrio spp. of interest admits isolates recovered from TS WWTP and receiving water bodies (Tsomo river) for each season. Vc, V. cholerae; Vm, V. mimicus; Vp, V. parahaemolyticus; Vf, V. fluvialis; Vv, V. vulnificus; Vg, Vibrio genus; (b): Percentage distribution of Vibrio spp. of interest among the isolates recovered from the AL WWTP and receiving water bodies (Boesman river) for each season. Va, V. alginolyticus; Vc, V. cholerae; Vm, V. mimicus; Vp, V. parahaemolyticus; Vf, V. fluvialis; Vv, V. vulnificus; Vg, Vibrio genus.

\section{Discussions}

In many countries, especially in the developing world, freshwater resources are severely contaminated with pathogens leading to various waterborne disease outbreaks [32]. Vibrio species occur naturally typically surviving in freshwater and marine environments. Their existence and role in human infections and Vibrio-facilitated biotransformation and remineralisation processes have been well documented [33-36]. In addition, the discharge of inadequately treated effluent in surface water often result in fluctuation of microbial com- 
munity, with consequences to water quality and water-borne pathogen contamination [37]. Recently, [38] reported that microbial community structure of freshwater resources are largely shaped by several key physicochemical variables. These environmental parameters are important factors in ascertaining the transmission of pathogens and environmental persistence (disease ecology). They are usually employed in projecting and preventing cases of infectious disease outbreaks arising from waterborne pathogens $[39,40]$.

On the other hand, the receiving water bodies higher bacterial density may cause rapid depletion of DO due to the higher rate of decomposition of organic matter, which are more abundant through discharged effluent from WWTP [41]. This explains why a negative correlation between DO and Vibrio density in surface waters nearby wastewater discharge point was observed in this study. The microorganisms' correlation with TSS and TDS show them as agents of major drivers of either spatiotemporal distribution of the bacteria in aquatic milieu or as factors needed to sustain their physiological status within the environment. The strong correlations between conductivity and TDS, conductivity and salinity and TDS and salinity could be ascribed to their reliant on ionic effluence loadings of freshwaters resources. The findings from this study are slightly in agreement with [42], where turbidity positively and significantly stimulate bacterial load.

Temperature is regarded as one of the most important factors affecting microbial growth and survival in the environment $[15,43]$. Positive correlation exhibited by temperature indicates its importance on distribution and abundance of Vibrio spp. in freshwater. Most recently, several studies have reported a varying range in temperature requirements for Vibrio species growth. Their findings further revealed that these pathogens grow extremely well at a mesophilic temperature range of 15 to $45{ }^{\circ} \mathrm{C}$ for most strains $[44,45]$. The significant difference observed in the presumptive seasonal density of Vibrio species portrays difference in season and sampling sites with respect to the month of sampling. The low presumptive densities during Winter (June-August in South Africa) are associated with low temperatures, suggesting that Vibrio species might have reverted to the viable but non-culturable (VBNC) state during Winter, when environmental factors become unfavourable [44]. Outbreaks of Vibrio infections usually occur in the warm months of the year [46]; hence, public health officers should be more vigilant for Vibrio infections outbreaks during this period.

Most South African wastewater treatment works disinfect wastewater by chlorination prior to discharge into receiving watersheds [47]. The goal is to remove pathogens from wastewater. Moreover, chlorine can be harmful to aquatic life if high concentrations are discharged into the environment [48]. It is, therefore, regulated before being discharged into the environment as free or residual chlorine in South Africa [49]. To achieve this goal, residual chlorine is maintained at sufficient levels and in contact with the microbial community in the chlorination tank. The residual chlorine concentration in this study ranged between 0.00 and $1.41 \mathrm{mg} / 1$ (Tables S1 and S2). The chlorine residual concentration fell below the minimum recommended concentration in TS WWTP and exceeded the maximum limit of $0.6 \mathrm{mg} / 1$ in AL WWTP of the year under review, except during the autumn season and July 2017. Similar ranges have been reported for chlorine residual concentration in South African wastewater treatment plants [50] and indicate that some South African waterworks do not comply with stipulated standards with reference to free chlorine residual concentration. A positive correlation was observed between chlorine residual concentration and Vibrio density (Table 6); the abundance of Vibrio species shows they can withstand the presence of residual chlorine in the treated effluents. The high residual chlorine concentration detected confirmed that the dosed chlorine was more than sufficient and possibly indicated the presence of chlorine-resistant strains of Vibrio species. 
Table 6. $p$ values showing significant differences in the average seasonal PCR confirmed Vibrio species in TS and AL wastewater treatment plants.

\begin{tabular}{cccc}
\hline \multicolumn{2}{c}{ TS Wastewater Treatment Plant } & \multicolumn{2}{c}{ AL Wastewater Treatment Plant } \\
\hline Seasons & $p$ values & Seasons & $p$ values \\
Summ vs. Autu & $0.108^{*}$ & Summ vs. Autu & $0.055^{*}$ \\
Summ vs. Wint & $0.001^{*}$ & Summ vs. Wint & $<0.0001^{*}$ \\
Summ vs. Spri & $0.003^{*}$ & Summ vs. Spri & $<0.0001^{*}$ \\
Autu vs. Wint & $0.013^{*}$ & Autu vs. Wint & $0.002^{*}$ \\
Autu vs. Spri & 0.37 & Autu vs. Spri & $0.006^{*}$ \\
Wint vs. Spri & 0.516 & Wint vs. Spri & 0.376 \\
\hline
\end{tabular}

*, significantly different; Summ, Summer; Autu, Autumn; Wint, Winter; Spri, Spring.

However, faulty clarifiers, sludge reticulation due to aerator breakdown and stabilization ponds that are not associated with disinfection have been identified during sampling regime with high Vibrio densities. These observations were consistent with the findings of [47] that reported polluted effluents in their study.

Our findings show that successful isolation and identification of varying Vibrio species via membrane filtration and molecular (PCR) methods reveal the large-scale presence of waterborne pathogens in treated wastewater effluents, reaffirming their ability to thrive and survive conventional wastewater treatment processes, as previously reported [51,52]. Vibrio species were recovered from all samples assessed throughout the sampling regime of this study. In line with our observation, the occurrence and prevalence of Vibrio species in wastewater have been documented by other researchers [14,53,54]. Our finding implies that there exists risk of infection with the potential pathogenic Vibrio species from effluents and their receiving water bodies. The infectious dose of $V$ cholerae required to cause clinical disease varies by the mode of administration; with water $10^{3}-10^{6}$ organisms and food, fewer organisms $\left(10^{2}-10^{4}\right)$ are required to produce disease. Vibrio species are capable of causing gastroenteritis, septicaemia and wound infection and may be deadly for persons in immune-compromised state, though the resulting infection is frequently self-limited [55].

Ref. [56] also recorded the abundance of Vibrio species in treated effluents during the Summer season. The detection of six notable Vibrio pathogens ( $V$. cholerae, $V$. mimicus, $V$, alginolyticus, $V$. fluvialis, $V$. vulnificus and V. parahaemolyticus) from TS and AL WWTPs is consistent with the observation of [57] that the abundance of Vibrio species varied widely in environmental waters. This findings further strengthens existing calls for the inclusion of emerging bacterial pathogens, including Vibrio species, as water quality indicators by the South African Department of Water Affairs.

Our observation on both wastewater treatment revealed it is a high risk to plants with potential danger to the environment, which calls for urgent attention. The recent Green Drop report (2014), which serves as a means of regulating WWTPs in South Africa, categorized TS and AL WWTPs as critical and high-risk WWTPs, respectively, further supports our observations [58,59]. The Green Drop of 2014 identified some of the challenges facing the AL and TS WWTPs, which includes effluent non-compliance, failure of wastewater treatment plant response management and operating capacity that exceeds design capacity. This finding indicates that treated effluents could serve as maintenance reservoirs for dominant Vibrio species (V. cholerae and Vibrio mimicus) amidst the confirmed Vibrio pathogens. The treated effluents could also serve as transient reservoirs for Vibrio alginoliticus and Vibrio vulnificus. These results correspond well with the data obtained from the study in the Eastern Cape Province, South Africa and United Kingdom [60,61]. The direct isolation and confirmation of Vibrio pathogens from TS and AL WWTPs further revealed the influence of seasonal variations such as temperature that affect the distribution of Vibrio pathogens in aquatic milieu [38,62].

Consequently, the persistence of these pathogens in treated effluents could be attributed to the impact of water run-offs carrying intestinal waste from livestock in neighbouring public slaughterhouses, birds and healthy carriers among the local human population [63], making the sewage conducive for the survival and proliferation of enteric 
pathogens, such as Vibrio species [14]. The recovery of notable non-halophilic (V. cholerae and V. mimicus) and halophilic ( $V$, alginolyticus, V. fluvialis, V. vulnificus and V. parahaemolyticus) Vibrio species in the same niche in this study is significant for the following reasons. First, the risk of acquiring infections associated with these pathogens might be on the rise, considering the concentration and diversity of Vibrio pathogens found within the same niche. Secondly, the coexistence of the various Vibrio species might result in interspecies interaction and the potential exchange of virulent gene markers through horizontal gene transfers [64]. Some of the known traits of Vibrio pathogens can be linked with quorum sensing, since these bacteria have been reported to be able to express their virulence factors through signalling molecules [65]. The surge in cases of infection could be partially attributed to global warming, as several, sporadic reports of V. alginolyticus, Vibrio vulnificus and Vibrio parahaemolyticus infections have also been recognized in regions with temperate climates, e.g., the United States of America [66] and, more recently, in Europe [15].

\section{Conclusions}

The results obtained via conventional bacteriology, with the aid of membrane filtration technique and PCR, show the treated effluents and receiving water bodies as environmental reservoirs of Vibrio pathogens considered in this study. Perpetually changing environmental conditions such as increasing surface water temperatures can significantly influence the risk of infections related to potentially human-pathogenic Vibrio species. Such changes may also affect temperate regions with mild subtropical climates such as the South Africa. Detection of high residual chlorine concentrations were observed; thus, this calls for concern on the issue of chlorine dosing because higher residual concentrations that are not compliant to both South Africa and general standards are being discharged into the environment, which is not good for aquatic life. Therefore, augmenting the inefficient chlorine disinfection process at the current plant with maturation ponds, ozonation or ultraviolet radiation could undoubtedly aid the treatment plants in discharging treated effluents with zero Vibrio species. Considering, the public health implication in the use of inadequately treated effluents, we advocate for regular monitoring of water reservoirs for possible microbial pathogens to allow for early response by public health authorities (e.g., prevention and treatment measures to combat relevant diseases). We further recommend regular monitoring of water reservoirs (treated effluents and receiving water bodies) to ensure early control of potential outbreaks of vibriosis and cholera.

Supplementary Materials: The following are available online at https: / www.mdpi.com/article/ 10.3390/w13070932/s1, Table S1: Tsomo WWTP microbial load and physicochemical, Table S2: Alicedale WWTP microbial load and physicochemical.

Author Contributions: A.I.O., conceptualization, provided materials for the study, proof-read the manuscript; A.C.O., conceptualization, structured the methods used in the study, carried out the experiments, wrote the original draft; O.E.A., optimized the methods and analysed the data. All authors have read and agreed to the published version of the manuscript.

Funding: We thank the South Africa Medical Research Council and the South Africa Water Research Commission for financial support.

Institutional Review Board Statement: Not applicable.

Informed Consent Statement: Not applicable.

Data Availability Statement: All data generated or analysed during this study are included in this manuscript.

Acknowledgments: We also thank Fiyin Olaitan for her assistance in editing the whole manuscript.

Conflicts of Interest: We have no conflicts of interest to disclose. 


\section{References}

1. Al-Gheethi, A.A.; Efaq, A.N.; Bala, J.D.; Norli, I.; Abdel-Monem, M.O.; Kadir, M.A. Removal of pathogenic bacteria from sewage-treated effluent and biosolids for agricultural purposes. Appl. Water Sci. 2018, 82, 74. [CrossRef]

2. Pandey, P.K.; Kass, P.H.; Soupir, M.L.; Biswas, S.; Singh, V.P. Contamination of water resources by pathogenic bacteria. $A M B$ Express 2014, 4, 1-16. [CrossRef]

3. Cai, L.; Zhang, T. Detecting human bacterial pathogens in wastewater treatment plants by a high-throughput shotgun sequencing technique. Environ. Sci. Technol. 2013, 47, 5433-5441. [CrossRef]

4. Cantalupo, P.G.; Calgua, B.; Zhao, G.; Hundesa, A.; Wier, A.D.; Katz, J.P.; Grabe, M.; Hendrix, R.W.; Girones, R.; Wang, D.; et al. Raw sewage harbors diverse viral populations. mBio 2011, 2. [CrossRef] [PubMed]

5. Chorev, N. The World Health Organization between North and South; Cornell University Press: Ithaca, NY, USA, 2012.

6. Oluseyi Osunmakinde, C.; Selvarajan, R.; Mamba, B.B.; Msagati, T.A. Profiling bacterial diversity and potential pathogens in wastewater treatment plants using high-throughput sequencing analysis. Microorganisms 2019, 7, 506. [CrossRef] [PubMed]

7. Aghalari, Z.; Dahms, H.U.; Sillanpää, M.; Sosa-Hernandez, J.E.; Parra-Saldívar, R. Effectiveness of wastewater treatment systems in removing microbial agents: A systematic review. Glob. Health 2020, 16, 13. [CrossRef] [PubMed]

8. Becerra-Castro, C.; Lopes, A.R.; Vaz-Moreira, I.; Silva, E.F.; Manaia, C.M.; Nunes, O.C. Wastewater reuse in irrigation: A microbiological perspective on implications in soil fertility and human and environmental health. Environ. Int. 2015, 75, 117-135. [CrossRef]

9. Osunla, C.A.; Okoh, A.I. Vibrio pathogens: A public health concern in rural water resources in Sub-Saharan Africa. Int. J. Environ Res. Public Health 2017, 14, 1188. [CrossRef]

10. Miyoshi, S.I. Extracellular proteolytic enzymes produced by human pathogenic Vibrio species. Front. Microbiol. 2013, 4, 339. [CrossRef] [PubMed]

11. Lutz, C.; Erken, M.; Noorian, P.; Sun, S.; McDougald, D. Environmental reservoirs and mechanisms of persistence of Vibrio cholerae. Front. Microbiol. 2013, 4, 375. [CrossRef] [PubMed]

12. Eja, M.E.; Abriba, C.; Etok, C.A.; Ikpeme, E.M.; Arikpo, G.E.; Enyi-Idoh, K.H.; Ofor, U.A. Seasonal occurrence of Vibrios in water and shellfish obtained from the Great Kwa River Estuary, Calabar, Nigeria. Bull. Environ. Contam. Toxicol. 2008, 81, 245-248. [CrossRef]

13. Osuolale, O.; Okoh, A. Isolation and antibiotic profile of Vibrio spp. in final effluents of two wastewater treatment plants in the Eastern Cape of South Africa. BioRxiv 2018, 330456. [CrossRef]

14. Baron, S.; Larvor, E.; Chevalier, S.; Jouy, E.; Kempf, I.; Granier, S.A.; Lesne, J. Antimicrobial susceptibility among urban wastewater and wild shellfish isolates of non-O1/Non-O139 Vibrio cholerae from La Rance Estuary (Brittany, France). Front. Microbiol. 2017, 8, 1637. [CrossRef]

15. Baker-Austin, C.; Trinanes, J.; Gonzalez-Escalona, N.; Martinez-Urtaza, J. Non-cholera vibrios: The microbial barometer of climate change. Trends Microbiol. 2017, 25, 76-84. [CrossRef]

16. Momba, M.; Azab El-Liethy, M. Vibrio cholerae and Cholera biotypes. Glob. Water Pathog. Proj. Available online: https: / / www.waterpathogens.org/sites/default/files/Vibrio\%20cholerae\%20and\%20Cholera\%20biotypes_4.pdf (accessed on 22 September 2020).

17. Olaniran, A.O.; Nzimande, S.B.; Mkize, N.G. Antimicrobial resistance and virulence signatures of Listeria and Aeromonas species recovered from treated wastewater effluent and receiving surface water in Durban, South Africa. BMC Microbiol. 2015, 15, 1-10. [CrossRef]

18. Verlicchi, P.; Grillini, V. Surface water and groundwater quality in South Africa and mozambique-Analysis of the Most critical pollutants for drinking purposes and challenges in water treatment selection. Water 2020, 12, 305. [CrossRef]

19. American Public Health Association; American Water Works Association; Water Pollution Control Federation; Water Environment Federation. Standard Methods for the Examination of Water and Wastewater; American Public Health Association: Waldorf, MD, USA, 1915.

20. SABS. SANS 5221: 2011 South African National Standard Microbiological Analysis of Water General Test Methods; South African Bureau of Standards: Pretoria, South Africa, 2011; pp. 7-11.

21. Maugeri, T.L.; Carbone, M.; Fera, M.T.; Gugliandolo, C. Detection and differentiation of Vibrio vulnificus in seawater and plankton of a coastal zone of the Mediterranean Sea. Res. Microbiol. 2006, 157, 194-200. [CrossRef] [PubMed]

22. Kwok, A.Y.; Wilson, J.T.; Coulthart, M.; Ng, L.K.; Mutharia, L.; Chow, A.W. Phylogenetic study and identification of human pathogenic Vibrio species based on partial hsp 60 gene sequences. Can. J. Microbiol. 2002, 48, 903-910. [CrossRef] [PubMed]

23. Okoh, A.I.; Sibanda, T.; Nongogo, V.; Adefisoye, M.; Olayemi, O.O.; Nontongana, N. Prevalence and characterisation of noncholerae Vibrio spp. in final effluents of wastewater treatment facilities in two districts of the Eastern Cape Province of South Africa: Implications for public health. Environ. Sci. Pollut. Res. 2015, 22, 2008-2017. [CrossRef] [PubMed]

24. Menezes, F.G.; Neves, S.D.; Sousa, O.V.; Vila-Nova, C.M.; Maggioni, R.; Theophilo, G.N.; Hofer, E.; Vieira, R.H. Detection of virulence genes in environmental strains of Vibrio cholerae from estuaries in northeastern Brazil. Rev. Inst. Med. Trop. São Paulo 2014, 56, 427-432. [CrossRef]

25. Goel, A.K.; Jain, M.; Kumar, P.; Jiang, S.C. Molecular characterization of Vibrio cholerae outbreak strains with altered El Tor biotype from southern India. World J. Microbiol. Biotechnol. 2010, 26, 281-287. [CrossRef] 
26. Tarr, C.L.; Patel, J.S.; Puhr, N.D.; Sowers, E.G.; Bopp, C.A.; Strockbine, N.A. Identification of Vibrio isolates by a multiplex PCR assay and rpoB sequence determination. J. Clin. Microbiol. 2007, 45, 134-140. [CrossRef]

27. Osorio, C.R.; Klose, K.E. A region of the transmembrane regulatory protein ToxR that tethers the transcriptional activation domain to the cytoplasmic membrane displays wide divergence among Vibrio species. J. Bacteriol. 2000, 182, 526-528. [CrossRef]

28. Guardiola-Avila, I.; Acedo-Felix, E.; Sifuentes-Romero, I.; Yepiz-Plascencia, G.; Gomez-Gil, B.; Noriega-Orozco, L. Molecular and genomic characterization of Vibrio mimicus isolated from a frozen shrimp processing facility in Mexico. PLoS ONE 2016, 11, e0144885. [CrossRef]

29. Wei, S.; Zhao, H.; Xian, Y.; Hussain, M.A.; Wu, X. Multiplex PCR assays for the detection of Vibrio alginolyticus, Vibrio parahaemolyticus, Vibrio vulnificus and Vibrio cholerae with an internal amplification control. Diagn. Microbiol. Infect. Dis. 2014, 79, 115-118. [CrossRef]

30. Abioye, O.E.; Okoh, A.I. Limpet (Scutellastra cochlear) Recovered From Some Estuaries in the Eastern Cape Province, South Africa Act as Reservoirs of Pathogenic Vibrio Species. Front. Public Health 2018, 6, 237. [CrossRef]

31. Patel, C.B.; Shanker, R.; Gupta, V.K.; Upadhyay, R.S. Q-PCR based culture-independent enumeration and detection of Enterobacter: An emerging environmental human pathogen in riverine systems and potable water. Front. Microbiol. 2016, 7, 172. [CrossRef] [PubMed]

32. Pruzzo, C.; Gallo, G.; Canesi, L. Persistence of vibrios in marine bivalves: The role of interactions with haemolymph components. Environ. Microbiol. 2005, 7, 761-772. [CrossRef] [PubMed]

33. Zhang, X.; Lin, H.; Wang, X.; Austin, B. Significance of Vibrio species in the marine organic carbon cycle-A review. Sci. China Earth Sci. 2018, 61, 1357-1368. [CrossRef]

34. Rubio-Portillo, E.; Kersting, D.K.; Linares, C.; Ramos-Esplá, A.A.; Antón, J. Biogeographic differences in the microbiome and pathobiome of the coral Cladocora caespitosa in the Western Mediterranean Sea. Front. Microbiol. 2018, 9, 22. [CrossRef] [PubMed]

35. Gorrasi, S.; Pasqualetti, M.; Franzetti, A.; Pittino, F.; Fenice, M. Vibrio communities along a salinity gradient within a marine saltern hypersaline environment (Saline di Tarquinia, Italy). Environ. Microbiol. 2020, 22, 4356-4366. [CrossRef]

36. Preisner, M. Surface Water Pollution by Untreated Municipal Wastewater Discharge Due to a Sewer Failure. Environ. Process. 2020, 7, 767-780. [CrossRef]

37. Ibekwe, A.M.; Ma, J.; Murinda, S.E. Bacterial community composition and structure in an Urban River impacted by different pollutant sources. Sci. Total Environ. 2016, 566, 1176-1185. [CrossRef]

38. Haque, M.A.; Jewel, M.A.; Sultana, M.P. Assessment of physicochemical and bacteriological parameters in surface water of Padma River, Bangladesh. Appl. Water Sci. 2019, 9, 1-8. [CrossRef]

39. Chase, E.; Harwood, V.J. Comparison of the effects of environmental parameters on growth rates of Vibrio vulnificus biotypes I, II, and III by culture and quantitative PCR analysis. Appl. Environ. Microbiol. 2011, 77, 4200-4207. [CrossRef]

40. Gutiérrez-Salazar, G.J.; Molina-Garza, Z.J.; Hernández-Acosta, M.; García-Salas, J.A.; Mercado-Hernández, R.; Galaviz-Silva, L. Pathogens in Pacific white shrimp (Litopenaeus vannamei Boone, 1931) and their relationship with physicochemical parameters in three different culture systems in Tamaulipas, Mexico. Aquaculture 2011, 321, 34-40. [CrossRef]

41. Jin, D.; Kong, X.; Cui, B.; Jin, S.; Xie, Y.; Wang, X.; Deng, Y. Bacterial communities and potential waterborne pathogens within the typical urban surface waters. Sci. Rep. 2018, 8, 1-9. [CrossRef]

42. Vezzulli, L.; Colwell, R.R.; Pruzzo, C. Ocean warming and spread of pathogenic vibrios in the aquatic environment. Microb. Ecol. 2013, 65, 817-825. [CrossRef]

43. Montánchez, I.; Ogayar, E.; Plágaro, A.H.; Esteve-Codina, A.; Gómez-Garrido, J.; Orruño, M.; Arana, I.; Kaberdin, V.R. Analysis of Vibrio harveyi adaptation in sea water microcosms at elevated temperature provides insights into the putative mechanisms of its persistence and spread in the time of global warming. Sci. Rep. 2019, 9, 1-12. [CrossRef]

44. Vezzulli, L.; Grande, C.; Reid, P.C.; Hélaouët, P.; Edwards, M.; Höfle, M.G.; Brettar, I.; Colwell, R.R.; Pruzzo, C. Climate influence on Vibrio and associated human diseases during the past half-century in the coastal North Atlantic. Proc. Natl. Acad. Sci. USA 2016, 113, E5062-E5071. [CrossRef]

45. Brenzinger, S.; van der Aart, L.T.; van Wezel, G.P.; Lacroix, J.M.; Glatter, T.; Briegel, A. Structural and proteomic changes in viable but non-culturable Vibrio cholerae. Front. Microbiol. 2019, 10, 793. [CrossRef]

46. Dechet, A.M.; Yu, P.A.; Koram, N.; Painter, J. Nonfoodborne Vibrio infections: An important cause of morbidity and mortality in the United States, 1997-2006. Clin. Infect. Dis. 2008, 46, 970-976. [CrossRef] [PubMed]

47. Makuwa, S.; Tlou, M.; Fosso-Kankeu, E.; Green, E. Evaluation of fecal coliform prevalence and physicochemical indicators in the effluent from a wastewater treatment plant in the north-west province, South Africa. Int. J. Environ. Res. Public Health 2020, 17, 6381. [CrossRef]

48. Manning, T.M.; Wilson, S.P.; Chapman, J.C. Toxicity of chlorine and other chlorinated compounds to some Australian aquatic organisms. Bull. Environ. Contam. Toxicol. 1996, 56, 971-976. [CrossRef] [PubMed]

49. Government Gazette. National Water Act: Revision of General Authorisations, No. 36820; Government Gazette: Pretoria, South Africa, 2013; pp. 3-31.

50. Momba, M.N.; Osode, A.N.; Sibewu, M. The impact of inadequate wastewater treatment on the receiving water bodies-Case study: Buffalo City and Nkokonbe Municipalities of the Eastern Cape Province. Water SA 2006, 32. [CrossRef]

51. Martone-Rocha, S.; Piveli, R.P.; Matté, G.R.; Dória, M.C.; Dropa, M.; Morita, M.; Peternella, F.A.; Matté, M.H. Dynamics of Aeromonas species isolated from wastewater treatment system. J. Water Health 2010, 8, 703-711. [CrossRef] 
52. Lafdal, M.Y.; Malang, S.; Toguebaye, B.S. Antimicrobial susceptibility of aeromonads and coliforms before and after municipal wastewater treatment by activated sludge under arid climate. Int. J. Microbiol. Res. 2012, 3, 174-180.

53. Dungeni, M.; van Der Merwe, R.R.; Momba, M. Abundance of pathogenic bacteria and viral indicators in chlorinated effluents produced by four wastewater treatment plants in the Gauteng Province, South Africa. Water SA 2010, 36. [CrossRef]

54. Ye, L.; Zhang, T. Bacterial communities in different sections of a municipal wastewater treatment plant revealed by $16 \mathrm{~S}$ rDNA 454 pyrosequencing. Appl. Microbiol. Biotechnol. 2013, 97, 2681-2690. [CrossRef]

55. Ho, H.; Amin, H.; Lee, H.R. Vibrio Infections; Medscape; Texas, Tech University Health Sciences Center: Houston, TX, USA, 2009; 12p.

56. Igbinosa, E.O.; Obi, L.C.; Tom, M.; Okoh, A.I. Detection of potential risk of wastewater effluents for transmission of antibiotic resistance from Vibrio species as a reservoir in a peri-urban community in South Africa. Int. J. Environ. Health Res. 2011, 21, 402-414. [CrossRef]

57. Kokashvili, T.; Whitehouse, C.A.; Tskhvediani, A.; Grim, C.J.; Elbakidze, T.; Mitaishvili, N.; Janelidze, N.; Jaiani, E.; Haley, B.J.; Lashkhi, N.; et al. Occurrence and diversity of clinically important Vibrio species in the aquatic environment of Georgia. Front. Public Health 2015, 3, 232. [CrossRef]

58. DWAF: Department of Water Affairs. 2013 Green Drop Report; 2016. Available online: https://www.dws.gov.za/Documents/ GreenDropReport2009_ver1_web.pdf (accessed on 15 September 2020).

59. DWAF: Department of Water Affairs. 2014 Green Drop Report; 2016. Available online: https:/ /www.dws.gov.za/Documents / GreenDropReport2009_ver1_web.pdf (accessed on 15 September 2020).

60. Mara, D.; Horan, N.J. (Eds.) Handbook of Water and Wastewater Microbiology; Elsevier: Amsterdam, The Netherlands, 2003.

61. Nongogo, V.; Okoh, A.I. Occurrence of Vibrio pathotypes in the final effluents of five wastewater treatment plants in Amathole and Chris Hani District Municipalities in South Africa. Int. J. Environ. Res. Public Health 2014, 11, 7755-7766. [CrossRef] [PubMed]

62. Janelidze, N.; Jaiani, E.; Lashkhi, N.; Tskhvediani, A.; Kokashvili, T.; Gvarishvili, T.; Jgenti, D.; Mikashavidze, E.; Diasamidze, R.; Narodny, S.; et al. Microbial water quality of the Georgian coastal zone of the Black Sea. Mar. Pollut. Bull. 2011, 62, 573-580. [CrossRef]

63. Morris, J.G., Jr. Non-O group 1 Vibrio cholerae: A look at the epidemiology of an occasional pathogen. Epidemiol. Rev. 1990, 12, 179-191. [CrossRef]

64. Redondo-Salvo, S.; Fernández-López, R.; Ruiz, R.; Vielva, L.; de Toro, M.; Rocha, E.P.; Garcillán-Barcia, M.P.; de la Cruz, F. Pathways for horizontal gene transfer in bacteria revealed by a global map of their plasmids. Nat. Commun. 2020, 11, 1-13. [CrossRef]

65. Beshiru, A.; Okareh, O.T.; Okoh, A.I.; Igbinosa, E.O. Detection of antibiotic resistance and virulence genes of Vibrio strains isolated from ready-to-eat shrimps in Delta and Edo States, Nigeria. J. Appl. Microbiol. 2020, 129, 17-36. [CrossRef] [PubMed]

66. Newton, A.; Kendall, M.; Vugia, D.J.; Henao, O.L.; Mahon, B.E. Increasing rates of vibriosis in the United States, 1996-2010: Review of surveillance data from 2 systems. Clin. Infect. Dis. 2012, 54, S391-S395. [CrossRef] [PubMed] 